\title{
A Social Identity Theory of Leadership
}

\author{
Michael A. Hogg \\ School of Psychology \\ University of Queensland
}

\begin{abstract}
A social identity theory of leadership is described that views leadership as a group process generated by social categorization and prototype-based depersonalization processes associated with social identity. Group identification, as self-categorization, constructs an intragroup prototypicality gradient that invests the most prototypical member with the appearance of having influence; the appearance arises because members cognitively and behaviorally conform to the prototype. The appearance of influence becomes a reality through depersonalized social attraction processes that make followers agree and comply with the leader's ideas and suggestions. Consensual social attraction also imbues the leader with apparent status and creates a status-based structural differentiation within the group into leader(s) and followers, which has characteristics of unequal status intergroup relations. In addition, a fundamental attribution process constructs a charismatic leadership personality for the leader, which further empowers the leader and sharpens the leader-follower status differential. Empirical support for the theory is reviewed and a range of implications discussed, including intergroup dimensions, uncertainty reduction and extremism, power, and pitfalls of prototype-based leadership.
\end{abstract}

Over the past 25 years social psychology has placed relatively little emphasis on the study of leadership. This is probably associated with the well-documented decline during the 1960s and 1970s of interest in small group research, the associated ascendency of social cognition, the European emphasis on large scale intergroup relations, and the "outsourcing" of small group and leadership research to organizational and management departments (for historical overviews, see Abrams \& Hogg, 1998; Hogg \& Abrams, 1999; Jones, 1998; McGrath, 1997; Moreland, Hogg, \& Hains, 1994; Sanna \& Parks, 1997).

In recent years, however, the social identity perspective has begun to provide an integrative conceptual focus for a revival of interest among social psychologists in group phenomena and for a dynamic linkage of social cognitive and intergroup processes (Hogg \& Abrams, 1999; Moreland et al., 1994). This has generated social identity analyses of a diverse range of phenomena (e.g., Abrams \& Hogg, 1990, 1999; Capozza \& Brown, 2000; Ellemers, Spears, \& Doosje, 1999; Hogg \& Abrams,

This article was made possible by a research grant from the Australian Research Council.

I thank Kelly Fielding, Margaret Foddy, Sarah Hains, Leigh Morris, and Sherry Schneider for their various intellectual contributions to the development of some of the ideas presented in this article.

Requests for reprints should be sent to Michael A. Hogg, School of Psychology, University of Queensland, Brisbane, QLD 4072, Australia.E-mail: m.hogg@psy.uq.edu.au
1988; Robinson, 1996; J. C. Turner, Hogg, Oakes, Reicher, \& Wetherell, 1987; Worchel, Morales, Páez, \& Deschamps, 1998) and has provided a social cognitive framework for social psychology to reexamine leadership as a group process. In this article I describe a social identity theory of group leadership.

I develop the theory with an introduction to relevant aspects of social identity and self-categorization theory, and then I contextualize by a short dissertation on leadership research. I describe in some detail the empirical support for core components of the leadership theory with the emphasis on direct tests. In the latter part of the article, I draw out and describe some direct implications and extensions of the theory for a range of aspects of leadership.

\section{Brief Overview of Leadership Research}

Leadership has long been a focus of research for social psychology and the wider social sciences (e.g., Bass, 1990a; Chemers, 1987, 2001; Eagly, Karau, \& Makhijani, 1995; Fiedler \& House, 1994; Graumann \& Moscovici, 1986; Hollander, 1985; Stogdill, 1974; Yukl, 1981). In recent years, however, it has waned in popularity for mainstream social psychology and is instead more commonly researched in other disciplines, 
particularly organizational psychology (e.g., Wilpert, 1995; Yukl \& Van Fleet, 1992).

Although personality perspectives identify some personality correlates of leadership (e.g., talkativeness; Mullen, Salas, \& Driskell, 1989), and personality explains some variance in the emergence of leaders in initially leaderless groups (Kenny \& Zaccaro, 1983), scholars agree that personality alone is a relatively poor correlate of leadership (Stogdill, 1974; Yukl, 1981; but see Albright \& Forziati, 1995). An alternative, situational perspective is that almost anyone can be an effective leader if the circumstances are right (e.g., Bales, 1950; Sherif, 1966). In the 1960s, drawing on a third strand of research that described the actual behavior of leaders (e.g., Bales, 1950; Lippitt \& White, 1943; Stogdill, 1974), Fiedler $(1965,1971)$ introduced an interactionist model; the leadership effectiveness of a particular behavioral style is contingent on the favorability of the situation to that behavioral style. Fiedler's contingency theory is generally reasonably well supported (e.g., Strube \& Garcia, 1981) despite some continuing controversy (e.g., Peters, Hartke, \& Pohlmann, 1985).

Another perspective focuses on leadership as a dynamic product of transactions between leaders and followers (Bass, 1990b; Hollander, 1985; Lord \& Maher, 1991; Nye \& Simonetta, 1996). For example, because leaders play a significant role in helping followers achieve their goals, followers bestow power and status on leaders to restore equity. Relatedly, followers may try to redress the power imbalance in groups by gaining personal information about the leader. This is an attributional process that imbues the leader with charisma and thus additional power (Fiske, 1993; Fiske \& Dépret, 1996). Leaders may also accumulate "idiosyncrasy credit" with the group by conforming to group norms. This subsequently allows them to be innovative and effective leaders (Hollander, 1958; Hollander \& Julian, 1970).

Recent transactional leadership perspectives, mainly in organizational psychology (Wilpert, 1995), focus on transformational leadership. Charismatic leaders are able to motivate followers to work for collective goals that transcend self-interest and transform organizations (Bass, 1990b; Bass \& Avolio, 1993; see Mowday \& Sutton, 1993, for critical comment). This focus on charisma is particularly evident in "new leadership" research (e.g., Bass, 1985, 1990b, 1998; Bryman, 1992; Burns, 1978; Conger \& Kanungo, 1987, 1988), which proposes that effective leaders should be proactive, change oriented, innovative, motivating and inspiring, and have a vision or mission with which they infuse the group. They should also be interested in others and be able to create commitment to the group and extract extra effort from, and generally empower, members of the group.

Social psychology's emphasis on social cognition has produced an extension of implicit leadership the- ory (Hollander \& Julian, 1969) called leader categorization theory (e.g., Lord, Foti, \& DeVader, 1984; Nye \& Forsyth, 1991; Palich \& Hom, 1992; Rush \& Russell, 1988; also see Nye \& Simonetta, 1996). People have preconceptions about how leaders should behave in general and in specific leadership situations. These preconceptions are cognitive schemas of types of leader (i.e., categories of leader that are represented as person schemas) that operate in the same way as other schemas (see Fiske \& Taylor, 1991). When someone is categorized on the basis of their behavior as a leader, the relevant leadership schema comes into play to generate further assumptions about behavior. Leadership schemas vary in situational inclusiveness. Subordinate schemas apply only to specific situations (they may relate to specific status characteristics, as described by expectation states theory; e.g., Berger, Fisek, Norman, \& Zelditch, 1977; Ridgeway, 2001), whereas superordinate schemas apply to a wide range of situations and embody very general leadership characteristics. Good leaders are people who have the attributes of the category of leader that fits situational requirements. This perspective treats leader categories as nominal categories - that is, cognitive groupings of instances that share attributes but do not have any psychological existence as a real human group. Indeed, the notion of a social group only of leaders makes little sense; who would lead and who would follow? Leadership is viewed as a product of individual information processing, not as a structural property of real groups nor as an intrinsic or emergent property of psychological ingroup membership (see Hogg, 1996a).

\section{Commentary on Leadership Research and a New Direction}

With only a few notable exceptions, then, the recent study of leadership has been conducted outside of contemporary mainstream social psychology and so has not benefitted from some of the recent conceptual advances made within social psychology. Although most perspectives now recognize that leadership is a relational property within groups (i.e., leaders exist because of followers and followers exist because of leaders), there is no analysis of leadership that describes how leadership may emerge through the operation of ordinary social cognitive processes associated with psychologically belonging to a group.

In contrast, the most recent analytic emphasis is mainly on (a) individual cognitive processes that categorize individuals as leaders-the social orientation between individuals is not considered, and thus group processes are not incorporated; or (b) whether individuals have the charismatic properties necessary to meet the alleged transformational objectives of lead- 
ership-leadership is a matter of situationally attractive individual characteristics rather than group processes. Both these perspectives have recently invited some criticism for neglecting the effects of larger social systems within which the individual is embedded (e.g., Hall \& Lord, 1995; Haslam \& Platow, 2001; Lord, Brown, \& Harvey, 2001; Pawar \& Eastman, 1997). Lord et al. (2001) explained that leadership cannot be properly understood in terms of a leader's actions or in terms of abstract perceptual categories of types of leader, and that a paradigm shift in how we understand leadership is called for. Their solution is to explore a connectionist, or parallel constraint satisfaction, level model.

However, if leadership is indeed a structural feature of ingroups, then leaders and followers are interdependent roles embedded within a social system bounded by common group or category membership. Thus, leadership dynamics may be significantly affected by the social cognitive processes associated with group membership (and group behaviors), specifically the processes of self-categorization and depersonalization now believed to be responsible for social identity processes, group behavior, and intergroup relations. Leaders may emerge, maintain their position, be effective, and so forth, as a result of basic social cognitive processes that cause people

1. To conceive of themselves in terms of the defining features of a common and distinctive ingroup (i.e., self-categorization, or identification, in terms of the ingroup prototype).

2. To cognitively and behaviorally assimilate themselves to these features (i.e., cognitive and behavioral depersonalization in terms of the ingroup prototype producing ingroup stereotypic or normative perceptions, attitudes, feelings, and behaviors).

3. To perceive others not as unique individuals but through the lens of features that define relevant ingroup or outgroup membership (i.e., perceptual depersonalization of others in terms of the ingroup or outgroup prototype, producing stereotypical homogenization).

If leadership is produced by these group processes contingent on psychologically belonging to the group, then having the prototypical or normative characteristics of a psychologically salient ingroup (i.e., being a prototypical ingroup member) may be at least as important for leadership as being charismatic or having schema-consistent characteristics of a particular type or category of leader (i.e., being schematic of a nominal leader category).

My aim in this article is to show that a social identity analysis can provide this sort of new, group membership oriented analysis of leadership processes. First, I briefly review social identity and self-categori- zation theory, then describe the proposed leadership theory followed by empirical support for its core tenets, and finally I explore a range of specific implications, extensions, and future directions.

\section{Social Identity and Self-Categorization}

The social identity perspective contains a number of compatible and interrelated components and emphases, in particular an original emphasis by Tajfel and Turner and their associates on social identity, social comparison, intergroup relations, and self-enhancement motivation (often simply called social identity theory; e.g., Tajfel \& Turner, 1979) and a later cognitive emphasis by J. C. Turner and his associates on the categorization process (called self-categorization theory; e.g., J. C. Turner et al., 1987). Social identity theory and self-categorization theory have been extensively overviewed as an integrated whole elsewhere (e.g., Hogg, 1996a, 2000a, 2001; Hogg \& Abrams, 1988, 1999; Hogg, Terry, \& White, 1995; J. C. Turner, 1999).

\section{Social Identity and Intergroup Relations}

Tajfel (1972) introduced the idea of social identity to theorize how people conceptualize themselves in intergroup contexts, how a system of social categorizations "creates and defines an individual's own place in society" (p. 293). He defined social identity as "the individual's knowledge that he belongs to certain social groups together with some emotional and value significance to him of this group membership" (Tajfel, 1972, p. 292). Because groups only exist in relation to other groups, they derive their descriptive and evaluative properties, and thus their social meaning, in relation to these other groups.

Furthermore, because social identity is self-evaluative and derives its value from the evaluative properties of the ingroup, social comparisons between groups are focused on establishing evaluatively positive distinctiveness for one's own group. Intergroup relations involve a process of competition for positive identity (J. C. Turner, 1975) in which groups and their members strive to protect or enhance positive distinctiveness and positive social identity. The specific way this occurs is governed by people's subjective understanding of the psychological permeability of group boundaries and the stability and legitimacy of status relations between groups (Tajfel \& Turner, 1979). This aspect of social identity theory has had a significant impact on social psychology (see Ellemers, 1993; Hogg \& Abrams, 1988). 


\section{Self-Esteem Hypothesis}

The drive for evaluatively positive social identity through positive distinctiveness is underpinned by a basic human need for positive self-esteem (e.g., J. C. Turner, 1982; J. C. Turner, Brown, \& Tajfel, 1979), a self-enhancement motive. The implication is that self-esteem motivates social identification and group behavior, and social identification satisfies the need for self-esteem (Abrams \& Hogg, 1988). Reviews of research on this self-esteem hypothesis reveal inconsistent findings that suggest a distinction between individual and group membership based self-esteem, and that the relationship between self-esteem and group behavior may be affected by other variables such as self-esteem extremity, identity strength, and group threat (see Abrams \& Hogg, 1988; Hogg \& Abrams, 1990; Long \& Spears, 1997; Rubin \& Hewstone, 1998). Crocker and her colleagues (e.g., Crocker, Blaine, \& Luhtanen, 1993; Crocker \& Luhtanen, 1990; Luhtanen \& Crocker, 1992) have explored self-esteem processes in intergroup behavior extensively and have developed a collective self-esteem scale that some researchers employ as a measure of social identity.

\section{Self-Categorization, Prototypicality, and Depersonalization}

The cognitive dimension of social identity is specified by self-categorization theory (J. C. Turner, 1985; J. C. Turner et al., 1987) in terms of the causes and consequences of social categorization of self and others (Hogg, 2001). The process of social categorization perceptually segments the social world into ingroups and outgroups that are cognitively represented as prototypes. These prototypes are context specific, multidimensional fuzzy sets of attributes that define and prescribe attitudes, feelings, and behaviors that characterize one group and distinguish it from other groups. Social categorization of other people perceptually assimilates them to the relevant ingroup or outgroup prototype and thus perceptually accentuates prototypical similarities among people in the same group and prototypical differences between people from different groups; there is an accentuation effect (e.g., Tajfel, $1959,1969)$ that underpins stereotyping. This overall process is called depersonalization because people are not viewed as unique and multifaceted individuals but as matches to the relevant ingroup or outgroup prototype; prototypicality, not individuality, is the focus of attention. Depersonalization refers to change in the basis of perception; it does not have the negative connotations of deindividuation or dehumanization.

Social categorization of self, self-categorization, has the same effect but more so. It not only depersonal- izes self-perception but goes further in actually transforming self-conception and assimilating all aspects of ones attitudes, feelings, and behaviors to the ingroup prototype; it changes what people think, feel, and do. Depersonalization is the basic process underlying group phenomena; it perceptually differentiates groups and renders perceptions, attitudes, feelings, and behaviors stereotypical and group normative.

Prototypes are often stored in memory to be "called forth" by social categorization in a particular context to guide perception, self-conception, and action. However, they are almost always modified to varying degrees, and they can be entirely constructed by specifics of a particular social context. Prototypes are contextually responsive, and the principle governing this contextual sensitivity is metacontrast. New prototypes form, or existing ones are modified, in such a way as to maximize the ratio of perceived intergroup differences to intragroup similarities; prototypes form to accentuate similarities within a category and differences between categories.

\section{Social Attraction Hypothesis}

Depersonalization affects people's feelings about one another. They become based on perceived prototypicality (called social attraction) rather than idiosyncratic preferences or personal relationships (called personal attraction), which is the social attraction hypothesis (Hogg, 1992, 1993; for direct empirical tests, see Hogg, Cooper-Shaw, \& Holzworth, 1993; Hogg \& Hains, 1996, 1998; Hogg \& Hardie, 1991; Hogg, Hardie, \& Reynolds, 1995). Ingroup members are liked more than outgroup members because the former are perceptually assimilated to a relatively positive ingroup prototype, or because their prototypical similarity to self is perceptually accentuated, or because self-liking (self-esteem) is extended to embrace people who are to some extent now viewed as prototypical extensions of self. Within the ingroup there is consensual liking that is stronger for more prototypical than for less prototypical members; there is a prototype-based social attraction gradient.

\section{Uncertainty Reduction Hypothesis}

It has recently been suggested that social identity processes are not only motivated by self-enhancement (the self-esteem hypothesis) but also by an epistemic or self-evaluative motive to reduce subjective uncertainty (the uncertainty reduction hypothesis; Hogg, 2000b; Hogg \& Abrams, 1993; Hogg \& Mullin, 1999; for direct empirical evidence, see Grieve \& Hogg, 1999; Hogg \& Grieve, 1999; Jetten, Hogg, \& Mullin, 
2000; Mullin \& Hogg, 1998, 1999). This motive is closely tied to social categorization.

Subjective uncertainty about important, usually self-conceptually relevant matters is aversive; thus, subjective uncertainty reduction is a powerful human motive. The processes of self-categorization and prototype-based depersonalization reduce uncertainty because perceptions, attitudes, feelings, and behavior are now prescribed by an ingroup prototype that usually has consensual validation from other group members. Groups with high entitativity (e.g., Campbell, 1958; see Brewer \& Harasty, 1996; Hamilton \& Sherman, 1996), with clear, unambiguous, and consensual prototypes, and which are located in a clearly delineated intergroup structure, are most effective at reducing subjective uncertainty.

\section{Salience}

A key question for social identity theory is what causes social identity (as defined earlier) as opposed to personal identity (self-conception in terms of unique properties of self or of one's personal relationships with specific other individuals), or one social identity rather than another, to become the contextually salient basis of perception, thought, and behavior? Theory and research suggest that there is an interaction between category accessibility and category fit (e.g., Oakes, Haslam, \& Turner, 1994) that operates within the motivational framework provided by self-esteem and uncertainty reduction (see Hogg, 1996a, 2001).

People, influenced by self-enhancement and uncertainty reduction motives, categorize the social context in terms of categories, represented as prototypes, which are chronically accessible in memory or rendered accessible by the immediate context, or both. That categorization becomes salient, which best accounts for relevant similarities and differences among people in the context (structural or comparative fit), which best accords with the social meaning of the context (normative fit), and which best satisfies self-enhancement and self-evaluative concerns. Situational cues or personal agenda, or both, cause people to "try out" different categories or prototypes to make sense of the social field in ways that also evaluate self relatively favorably. This is a fast and relatively automatic cognitive perceptual iterative process that stabilizes when fit is optimized. Only then does self-categorization occur, in the sense of depersonalized self-conception, cognition, and behavior.

\section{Social Identity and Intragroup Processes and Structures}

Social identity theory originally focused on intergroup behavior in the context of large social categories: intergroup social comparisons, positive distinctiveness, stereotypes, discrimination, and intergroup relations. Intragroup behavior was generally treated as an unproblematic by-product of intergroup relations; ingroups were largely treated as homogenous and undifferentiated. In contrast, the recent emphasis on self-categorization and depersonalization has prompted recognition that groups are internally structured with respect to prototypicality. Within a group, some people are more prototypical than others. Therefore, depersonalized social identity processes within groups may involve differentiation among people that is not interpersonal but is genuinely grounded in common category membership.

Initially, this idea was explored in the context of group cohesion and social attraction (Hogg, 1992, 1993), and group polarization (e.g., Abrams, Wetherell, Cochrane, Hogg, \& Turner, 1990; McGarty, Turner, Hogg, David, \& Wetherell, 1992; see J. C. Turner, 1991), but it has subsequently produced other research on social identity-based intragroup processes (Hogg, 1996a, 1996b): for example, structural differentiation into subgroups within groups (e.g., Hornsey \& Hogg, 1999, 2000a, 2000b), and deviance and the "black sheep effect" (e.g., Marques \& Páez, 1994). However, perhaps the most basic and pervasive structural differentiation within groups is into leader(s) and followers.

\section{Social Identity, Self-Categorization, and Leadership}

Building on preliminary ideas in a book chapter (Hogg, 1996a), I describe how social identity processes influence leadership, followed in the next section by discussion of empirical support for these ideas. Leadership is about how some individuals or cliques have disproportionate power and influence to set agenda, define identity, and mobilize people to achieve collective goals. The differential ability of some people to stamp their mark on attitudes, practices, decisions, and actions is endemic to all social groups-for example, nations, communities, organizations, committees, cliques, and families. Leaders are people who have disproportionate influence, through possession of consensual prestige or the exercise of power, or both, over the attitudes, behaviors, and destiny of group members. Leadership is very much a group process (Chemers, 2001). I propose that there are three core processes that operate in conjunction to make prototypicality an increasingly influential basis of leadership processes as a function of increasing social identity salience: prototypicality, social attraction, and attribution and information processing. These processes are described mainly in terms of emergent lead- 
ership in new groups. However, they also apply to situations in which established leadership roles are structurally assigned; this is explicitly addressed later.

\section{Prototypicality}

We have seen that when group membership is psychologically salient, social categorization of self and other ingroup members depersonalizes perception, cognition, affect, and behavior in terms of the contextually relevant ingroup prototype. The more salient the group the more profound is the effect. Group members conform to, and thus are influenced by, the prototype. Those people who are more prototypical to begin with will be less influenced than those who are less prototypical to begin with; the former make fewer changes than the latter to approximate the prototype. (For a review of evidence for prototypical depersonalization as the basis for conformity see J. C. Turner, 1991.) In salient groups, people are highly sensitive to prototypicality, as it is the basis of perception and evaluation of self and other group members. Thus, they notice and respond to even very subtle differences in how prototypical fellow members are; there is a clearly perceived gradient of prototypicality within the group, with some people perceived to be more prototypical than others (e.g., Haslam, Oakes, McGarty, Turner, \& Onorato, 1995; Hogg, 1993). Within a salient group then, people who are perceived to occupy the most prototypical position are perceived to best embody the behaviors to which other, less prototypical members are conforming. There is a perception of differential influence within the group, with the most prototypical member appearing to exercise influence over less prototypical members. In new groups, this is an "appearance" because the most prototypical person does not actively exercise influence; it is the prototype that he or she happens to embody that influences behavior. In established groups the appearance is backed up by actual influence (see following).

We have seen that prototypes are contextually sensitive to the intergroup social comparative context (the metacontrast principle). Thus, if the context remains unchanged, the prototype will remain unchanged, and the same individual group member will occupy the most prototypical position. It follows that the longer a particular individual occupies the most prototypical position, the stronger and more entrenched will be the appearance that he or she has actively exercised influence over others. In new groups this person is perceived to occupy an embryonic leadership role, although leadership has not been exercised. There is an embryonic role differentiation into leader and followers.
As group membership becomes more salient, and members identify more strongly with the group, prototypicality becomes an increasingly influential basis for leadership perceptions. People also, of course, rely on general and more task-specific schemas of leadership behaviors (what Lord and his colleagues call leader categories; e.g., Lord et al., 1984). However, the importance of these schemas is either unaffected by self-categorization, or they become less important as group prototypicality becomes more important. In either case, leadership schemas should become less influential relative to group prototypicality as group membership becomes psychologically more salient.

\section{Social Attraction}

Leadership is more than passively being a prototypical group member; it involves actively influencing other people. One way in which this is made possible is through the social attraction process. We have seen that self-categorization depersonalizes the basis of attraction within groups, such that more prototypical members are liked more than less prototypical members, and that where there is a consensual prototype this has the effect of producing consensually greater liking for prototypical members (e.g., Hogg, 1992, 1993). The person occupying the most prototypical position may acquire, in new groups, or possess, in established groups, the ability to actively influence because he or she is socially attractive and thus able to secure compliance with suggestions and recommendations he or she makes.

A well-researched consequence of liking is that it increases compliance with requests. If you like someone you are more likely to agree with them and comply with requests, suggestions, and orders (e.g., Berscheid \& Reis, 1998). In this way, the most prototypical person is able to exercise leadership by having his or her ideas accepted more readily and more widely than ideas suggested by others. This empowers the leader and publicly confirms his or her ability to exercise influence. Consensual depersonalized liking, particularly over time, confirms differential popularity and public endorsement of the leader. It imbues the leader with prestige and status and begins to reify an intragroup status differential between leader(s) and followers.

Social attraction may also be enhanced by the behavior of highly prototypical members. More prototypical members tend to identify more strongly and thus display more pronounced group behaviors; they will be more normative, show greater ingroup loyalty and ethnocentrism, and generally behave in a more group serving manner. These behaviors further confirm their prototypicality and thus enhance social attraction. A leader who acts as "one of us" by showing 
strong ingroup favoritism and intragroup fairness is not only more socially attractive but is also provided with legitimacy. Indeed, research on justice considerations in group contexts confirms that although distributive justice is complicated (intragroup fairness conflicting with intergroup bias), intragroup procedural justice is critical. According to the group value model of procedural justice, members feel more satisfied and more committed to the group if the leader is procedurally fair (Lind \& Tyler, 1988; Tyler, 1997; Tyler, DeGoey, \& Smith, 1996; Tyler \& Lind, 1992; also see Platow, Reid, \& Andrew, 1998).

\section{Attribution and Information Processing}

Prototypicality and social attraction work in conjunction with attribution and information processing to translate perceived influence into active leadership. As elsewhere, attribution processes operate within groups to make sense of others' behavior. Also as in other contexts, attributions for others' behavior are prone to the fundamental attribution error (Ross, 1977) or correspondence bias (Gilbert \& Jones, 1986; also see Gilbert \& Malone, 1995; Trope \& Liberman, 1993), a tendency to attribute behavior to underlying dispositions that reflect invariant properties, or essences, of the individual's personality. This effect is more pronounced for individuals who are perceptually distinctive (e.g., figural against a background) or cognitively salient (e.g., Taylor \& Fiske, 1978).

We have seen that when group membership is salient, people are sensitive to prototypicality and attend to subtle differences in prototypicality of fellow members. Highly prototypical members are most informative about what is prototypical of group membership (see J. C. Turner, 1991), and so, not surprisingly, in a group context they attract most attention. They are subjectively important and are distinctive or figural against the background of other less informative members. Research in social cognition shows that people who are subjectively important and distinctive are seen to be disproportionately influential and have their behavior dispositionally attributed (e.g., Erber \& Fiske, 1984; Taylor \& Fiske, 1975).

We have also seen how highly prototypical members may appear to have influence due to their relative prototypicality, and may actively exercise influence and gain compliance as a consequence of consensual social attraction. Together, the leadership nature of this behavior and the relative prominence of prototypical members is likely to encourage an internal attribution to intrinsic leadership ability, or charisma. This attribution will be facilitated if cultural theories of the causes of leadership favor the belief that leadership re- flects personality (e.g., in individualist cultures; see Morris \& Peng, 1994).

In groups, then, the behavior of highly prototypical members is likely to be attributed, particularly in stable groups over time, to the person's personality rather than the prototypicality of the position occupied. The consequence is a tendency to construct a charismatic leadership personality for that person that, to some extent, separates that person from the rest of the group and reinforces the perception of status-based structural differentiation within the group into leader(s) and followers. This may make the leader stand out more starkly against the background of less prototypical followers, as well as draw attention to a potential power imbalance, thus further fueling the attributional effect.

The fact that followers do tend to focus on the leader and make dispositional attributions for that person's behavior has some empirical support. Fiske (1993; Fiske \& Dépret, 1996) showed how followers pay close attention to leaders and seek dispositional information about leaders because detailed individualized knowledge helps redress the perceived power imbalance between leader and followers. Conger and Kanungo (1987, 1988) described how followers attributionally construct a charismatic leadership personality for organizational leaders who have a "vision" that involves substantial change to the group. Meindl, Ehrlich, and Dukerich (1985) showed that simplified dispositional attributions for leadership were more evident for distinctive leadership behaviors and under crisis conditions.

\section{Emergence and Endurance of Leaders}

Social identity processes associated with leadership do not only apply to emergent leaders but also to enduring and structurally designated leaders. Whether you are an emergent or an established leader, prototypicality processes influence leadership perceptions and effectiveness when group membership salience is elevated.

Under conditions of depersonalization, prototypicality becomes a significant basis for all leadership perceptions. In new groups, the associated processes of social attraction and prototype-based attribution and information processing can translate these perceptions into proactive leadership behavior. The longer an individual remains in a leadership position the more they will be socially liked, the more consensual will be the social attraction, and the more entrenched will be the fundamental attribution effect. Having acquired effective influence in these ways, the person occupying the prototypical position can, just like an established leader whose position is structurally designated, adopt more active aspects of being a leader, including the ability to actively maintain his or her leadership position. 
Although an established leader has the power base simply to maintain his or her position, it is often advantageous if the group continues to view them as highly prototypical. However, as we have seen, social contextual changes impact prototypicality. Thus, over time and across contexts, the leader may decline in prototypicality whereas other members become more prototypical, opening the door, particularly under high salience conditions, to a redistribution of influence within the group. An established leader is well placed in terms of resources to combat this by redefining, usually through rhetoric and polemic (e.g., Reicher \& Hopkins, 1996), the prototype in a self-serving manner to prototypically marginalize contenders and prototypically centralize self. This can be done by accentuating the existing ingroup prototype, by pillorying ingroup deviants, or by demonizing an appropriate outgroup. Generally all three tactics are used, and the very act of engaging in these tactics is often viewed as further evidence of effective leadership. National leaders often engage in these tactics. During the 1982 Falklands War between Britain and Argentina, Margaret Thatcher, the British Prime Minister, accentuated her nationalistic prototype of Britain, pilloried deviant groups within Britain who did not represent her prototype, and demonized the Argentinian outgroup. Her leadership ratings rose significantly.

Leadership endurance also benefits from consensual prototypicality because of the effect of consensual popularity on social attraction. In groups with less consensual prototypes, there is less consensus of perceptions of and feelings for the leader, and thus the leader may have less power and may occupy a less stable position. It is in the leaders's interest to maintain a consensual prototype. Simple and more clearly focused prototypes are less open to ambiguity and alternative interpretations and are thus better suited to consensuality. In addition, ingroup deviants serve an important function; by creating and rejecting such deviants the leader is well able to clarify the self-serving focus of the prototype. Another strategy is to polarize or extremitize the ingroup relative to a specific "evil" outgroup. Leaders can also accentuate or create intergroup conflict to achieve these ends (e.g., Rabbie \& Bekkers, 1978). These processes clearly operate in extremist groups with all-powerful leaders. For example, in Cambodia in the 1970s, Pol Pot constructed a simple and orthodox national prototype; he engaged in a campaign of prototypical purification that involved exterminating deviants, and he polarized from and demonized the "decadent" West.

\section{Tests of the Social Identity Theory of Leadership}

The central prediction from the social identity theory of leadership is that as people identify more strongly with a group, the basis for leadership percep- tions, evaluations, and endorsement becomes increasingly influenced by prototypicality; prototypical members are more likely to emerge as leaders, and more prototypical leaders will be perceived to be more effective leaders. This idea has been directly tested and supported in a series of studies.

Hains, Hogg, and Duck (1997) conducted a laboratory study of emergent leadership perceptions and evaluations in ad hoc and relatively minimal groups. Three independent variables (group salience, group prototypicality, and leader schema congruence) were manipulated in a $2 \times 2 \times 2$ design. Under conditions of high or low group salience, student participants $(N=$ 184) anticipated joining a small discussion group formed on the basis of attitude congruence. They were informed that a randomly appointed group leader was group prototypical or nonprototypical (group prototypicality) in terms of the attitude dimension and had a behavioral style (on the basis of a pretest) that was congruent or incongruent with a leader schema (leader schema congruence). Dependent measures were taken ostensibly in anticipation of the upcoming discussion. In addition to checks on each of the three manipulations, we also measured group identification (11-item scale) and perceived leader effectiveness (10-item scale). As predicted, when group membership was salient people identified more strongly with the group and endorsed the prototypical leader as being much more effective than the nonprototypical leader; low-salience participants did not differentiate between prototypical and nonprototypical leaders. Although leader schema congruent leaders were perceived overall to be more effective than schema incongruent leaders, we found that this effect disappeared for high-salience participants on one leadership effectiveness item. Although social attraction for the leader was not explicitly tested, the 10-item leadership effectiveness scale contained an item measuring liking for the leader; thus, leadership effectiveness was associated with liking.

To complement this highly controlled laboratory experiment, we conducted a naturalistic field study of leadership in small interactive "outward bound" groups in which real leaders emerged and actually lead the groups in wilderness and outdoor experiences (Fielding \& Hogg, 1997). There were 13 mixed-sex, approximately 11-person groups of people mainly in their 20s from around Australia $(N=143)$. The groups stayed together for 3 weeks. We replicated the laboratory experiment as closely as we could, but of course in a measurement-based regression format. Leadership schemas, group membership variables, and leadership effectiveness perceptions were measured a week to 10 days apart. In this study we were also able to measure social attraction. As predicted, (a) group identification, perceived leadership effectiveness, and social attraction for the leader increased over time as the group be- 
came a more cohesive entity; and (b) perceived leadership effectiveness was a positive function of social attraction for and group prototypicality of the leader, and this was amplified among high identifying participants. Perceived leader schema congruence of the leader was a predictor of perceived leadership effectiveness but was uninfluenced by identification.

We now returned to the laboratory where we conducted two minimal group studies based closely on Hains et al.'s (1997) methodology (Hogg, Hains, \& Mason, 1998). The main aim of these somewhat complex studies was to treat prototypicality and leadership as relativistic properties of a comparative frame of reference in which individuals are perceived and evaluated in relation to other individuals who are ingroup or outgroup members. The first study had student participants $(N=82)$ nominate a leader for a small high salience discussion group they were ostensibly going to join. They were provided with a carefully constructed transcript of an earlier meeting of the group that provided leadership schema congruence and group prototypicality information for each of the other members. They rated the group, their nominated leader and all other group members, and their identification with the group. The second study was a $2 \times 2 \times 2$ experiment $(N=164)$ in which group salience, leadership schema congruence of the leader, and group prototypicality of the leader were orthogonally manipulated. The key feature of this experiment was that the prototypicality of the leader was indirectly manipulated by constructing an intergroup comparative context that, on the basis of metacontrast, influenced the location of the prototype in precisely calculable ways.

Across these two studies, we found that leadership schema congruence became a less influential, and group prototypicality a more influential, determinant of leadership endorsement in more cohesive groups with which people identified more strongly. We also found, as expected, that identification accentuated perceived prototypical similarities between ingroup members and thus between leader and nonleaders, and that this weakened the prototype-leadership relation when leadership and prototypicality were measured relativistically (leaders relative to nonleaders). We argued, however, that this effect was due to the ad hoc and emergent nature of the group, and that over time the perceptual gulf between leader and followers, described by the theory, would gradually develop.

There is further support for the proposed theory from recent social identity-based research into leadership. I describe this work more briefly. First, Platow and van Knippenberg (1999) have recently replicated the finding from Hains et al. (1997) that prototypicality becomes an increasingly influential basis for leadership endorsement as group membership becomes more salient. Second, Duck \& Fielding (1999), drawing directly on the social identity theory of leadership, conducted two laboratory experiments that, in a relatively minimal way, simulated equal status subgroups nested within a larger organization (total of 328 participants). They measured group identification and evaluations of organization leaders who were randomly appointed from participants' own or the other subgroup. Ingroup, thus prototypical, leaders were more strongly supported than outgroup, thus nonprototypical, leaders, and this effect was more pronounced to the extent that participants identified strongly with their own subgroup. Again, the basis of leadership perception and endorsement is more firmly grounded in prototypicality as people identify more strongly with the group.

Platow, Reid, and Andrew (1998) provided some indirect support for the leadership theory from a laboratory experiment in which they manipulated group salience (interpersonal vs. intergroup context), and whether a randomly appointed leader was procedurally fair-unfair and distributively fair-unfair $(N=132)$. If it is assumed that fairness is a general property of leadership schemas, but that ingroup favoritism is a generally prototypical and socially attractive property of group membership, then we would predict that distributively and procedurally ingroup favoring leaders would be more strongly endorsed under high- than low-salience conditions. This is precisely what Platow and his colleagues found.

Haslam et al. (1998) reported three experiments (total $N=387$ ) that support the idea that systematically selected leaders may be less favorably perceived than randomly appointed leaders. They argue, from social identity theory, that this may be because a systematic selection process draws attention away from the group and toward individuality. It personalizes the leader and separates him or her from the group and thus renders the leader perceptually less prototypical. It may even also weaken group identification. In contrast, a random process keeps attention on the group as a whole. It does not personalize the leader, and thus allows him or her to be viewed as a prototypical group member. It may also strengthen group identification. Again, prototypicality becomes an increasingly important basis of leadership as group membership becomes more salient.

Finally, there are studies conducted within a social dilemmas tradition. Drawing on social identity theory and on Tyler and Lind's (1992) group value model, van Vugt and de Cremer (1999) conducted two experiments (total of 189 participants) in which they found that when people strongly identify with a group faced by a social dilemma they prefer a leader who shares the group's values (i.e., is prototypical) and believe that such a leader will actually be more effective. Van Vugt and de Cremer explicitly viewed this as supporting the social identity theory of leadership. In another social dilemma study, de Cremer and van Vugt (in press) manipulated a number of variables including how much 
participants identified with the group and how much a randomly appointed leader ostensibly identified with the group $(N=94)$. Dependent measures focused mainly on cooperation with the leader as a reflection of leader approval, support, and effectiveness. The results showed that members cooperated more with a highthan low-identifying leader, and that this was particularly the case for members who identified strongly with the group. In addition, the effect was clearly mediated by social attraction. De Cremer and van Vugt (in press) explicitly stated that these data support the social identity theory of leadership. Finally, Foddy and Hogg (1999) reported some data of their own that suggest that where there are leaders managing a scarce resource, those leaders who identify more strongly with the group (and thus consider themselves to be more prototypical) tend to be more conserving of the scarce resource and are thus more effective leaders.

In this section I have reviewed social identity research that directly tests or indirectly tests the leadership theory presented here. There is consistent and reliable support for the core idea that as groups become more salient and people identify more strongly with them, prototypicality of the leader becomes an increasingly significant basis for leadership perceptions. There is some evidence that as prototypicality becomes more important, leadership schema congruence becomes less important. There is also support for the idea that prototype-based depersonalized social attraction may facilitate leadership. There is some direct evidence from the studies by Fielding and Hogg (1997) and de Cremer and van Vugt (in press), whereas in other studies social attraction is a component of the leadership evaluation measure (e.g., Hains et al., 1997; Hogg et al., 1998). The attribution and associated structural differentiation components of the theory have indirect support (e.g., Fiske, 1993; Fiske \& Dépret, 1996), but remain to be directly tested.

\section{Some Implications, Extensions, and Future Directions}

The social identity theory of leadership has a number of qualifications, elaborations, and implications for our understanding of leadership processes. Although mainly speculative, these ideas point to promising directions for future research.

\section{Intergroup Context of Leadership}

Social identity theory is an intergroup theory, and thus the model presented here is an intergroup model of leadership. Leadership in salient groups can only be understood in its intergroup context, because groups can only be understood in their intergroup context. Prototypes are determined by metacontrast involving both intragroup and intergroup comparisons, and thus leadership is influenced by intergroup relations. In turn, although leaders provide a focus for ingroup members, they often lead their groups against outgroups and struggle to promote their group in competition with other groups (e.g., Rabbie $\&$ Bekkers, 1978). Also, as discussed earlier, leaders manipulate followers' intergroup representations and comparisons in ways that secure or promote tenure by ensuring that the leader is highly prototypical.

Groups often interact and communicate with one another through their leaders; indeed, most intergroup bargaining and negotiation is via group leaders. These are intergroup encounters. Social identity research shows that intergroup encounters generally strengthen identification and polarize prototypes (e.g., Abrams et al., 1990), and the proposed leadership theory suggests that leaders under high-salience conditions tend to be prototypical and highly identified with the group. We have also seen that justice considerations specify that leaders should be fair within groups but should favor ingroup over outgroup (e.g., Platow et al., 1998). Together, these ideas point to the clear prediction that intergroup bargaining tends to accentuate competitiveness, particularly when leaders feel accountable to and under surveillance by their group; research confirms this (e.g., Carnevale, Pruitt, \& Britton, 1979; Morley, Webb, \& Stephenson, 1988).

\section{Uncertainty Reduction and Leadership}

Social identity processes are motivated by self-enhancement (e.g., J. C. Turner, 1982) and by uncertainty reduction (e.g., Hogg, 2000b; Hogg \& Mullin, 1999). We have seen how depersonalized social attraction (e.g., Hogg, 1993), which perhaps owes more to self-enhancement, influences leadership. How might uncertainty reduction affect leadership?

As described earlier, the more that people feel self-conceptually uncertain about things that matter, the more they are inclined to identify with groups, particularly with groups that have clearly focused and consensual prototypes, groups that are often thought to be extreme. From a leadership perspective, these are precisely the conditions that favor prototype-based leadership that may be enduring enough to entrench a strong leader. Under high self-conceptual uncertainty, members strive for a simple and distinct prototype, support witch-hunts to purify the group of deviants, express consensual social attraction, are highly attuned to prototypicality, and invest the leader with a highly charismatic leadership personality.

A good example of this is "totalist" groups such as cults (e.g., Curtis \& Curtis, 1993; Galanter, 1989). In 
these groups, leaders are often distinct and remote from followers. There is a steep and rigid prestige differential between leaders and followers that provides a clearly delineated intragroup status structure. This arrangement contributes further to uncertainty reduction under conditions of extreme uncertainty because it imbues the intragroup structural arrangement, and thus the leader, with perceived legitimacy that protects the system from change (see Jost \& Banaji's, 1994, system justification theory). Leaders may also maintain or strengthen their leadership position through strategic management of uncertainty (see Marris's, 1996, notion that certainty is power). Specifically, they can deliberately raise uncertainty (e.g., the specters of war, economic collapse, cultural disintegration), and at the same time define a clear social identity predicated on a prototype that closely matches the leader. Uncertainty reduction automatically endorses the leader.

\section{Leadership, Influence, and Power}

Definitions of leadership usually distinguish leadership from power (e.g., Chemers, 2001; Lord et al., 2001). Leadership is a process of influenc that enlists and mobilizes the involvement of others in the attainment of collective goals; it is not a coercive process in which power is exercised over others. The social identity theory of leadership is consistent with this type of definition (Hogg \& Reid, 2001). Prototypical leaders do not need to exercise power to have influence; they are influential because of their position and the depersonalization process that assimilates members' behavior to the prototype. They and their suggestions are intrinsically persuasive because they embody the norms of the group; they have referent power (Raven, 1965 ), or position power, and therefore do not need to exercise personal power (Yukl \& Falbe, 1991). In addition to not needing to exercise power, it is possible that prototypical leaders may be unable to exercise power. High prototypicality is associated with strong ingroup identification; self and group are tightly fused prototypically, and thus any form of negative behavior directed against fellow members is effectively directed against self. There may exist an empathic bond between leader and followers that protects against any desire to exercise power over others let alone the destructive use of power or the abuse of power.

However, leaders sometimes do exercise power in harmful ways. Why does this happen? How can it be curbed? One possibility, based on the leadership theory, is that increasing status-based differentiation between leader and followers effectively instantiates an intergroup relationship. The empathic ingroup bond that protects against abuse of power is severed. In addition, the leader is now no longer prototypical for the followers. Leadership through ingroup prototype-based influence is no longer effective, therefore the leader now needs to, and can, gain influence by exercising power over other members of the group as if they were outgroup members. Such a relationship will be competitive and potentially exploitative, far removed from prototype-based leadership. This is likely to be more pronounced in hierarchical extremist groups in which leader-follower role differentiation is more tangible and stark, and in groups in which there is a leadership clique rather than a single leader. The potential for the abuse of power is likely to be much accentuated in these types of groups.

The progression from benign influence to destructive wielding of power can be curbed by anything that inhibits the process of structural differentiation and that regrounds leadership in prototypicality. External threat from an outgroup might be particularly effective in this regard, as it enhances identification and depersonalization and increases solidarity and social attraction (e.g., Hogg, 1993). Power may, paradoxically, also be curbed by quite the opposite circumstances. If a group becomes less cohesive, more diverse, and less consensual about its prototype, it is less likely that followers will endorse the same person as the leader. Thus, the leader's power base will fragment, and numerous new "contenders" may emerge. Although this limits the leader's ability to abuse power, it also undermines prototype-based leadership. Also note that leaders who have become accustomed to exercise power may vigorously resist any threats to their ability to exercise power.

The social identity analysis of leadership and power presented here is explored fully by Hogg and Reid (2001). It suggests that leaders only exercise power when the self-categorization contingent processes of social attraction and prototypical attribution structurally differentiate the leader from the rest of the group and thus change the leader-group relationship from an intragroup relationship into some form of unequal status intergroup relationship. The exercise of power now becomes associated with other intergroup behaviors (e.g., stereotyping, intergroup discrimination, social dislike) that inevitably widen the gulf between leaders and followers. This analysis remains to be formally tested; however, there is evidence that people in power do tend to stereotype followers (e.g., Fiske, 1993; Fiske \& Dépret, 1996; Goodwin \& Fiske, 1996; Goodwin, Gubin, Fiske, \& Yzerbyt, 2000).

\section{Pitfalls of Prototype-Based Leadership}

Prototype-based leadership can be very effective and mutually satisfying because there is no need to be coercive, and attitude change occurs automatically via the depersonalization process associated with self-categori- 
zation and social identification. However, we have seen that other processes such as social attraction and prototypical attribution can change the leader-follower relationship in ways that may have undesirable effects. There are some pitfalls to prototype-based leadership.

Processes associated with prototype-based leadership may, paradoxically, distance the leader from the group, sever the empathic intragroup bond, and reconstruct a form of intergroup relationship between leader and followers. This encourages stereotypic perception and treatment of followers, and the exercise of power to have influence; taken in tandem, this provides a framework for abuse of power that resembles the ethnocentric and competitive nature of intergroup behavior. It also allows leaders to engage in typically repressive dominant group strategies to protect their status from apparent threats (e.g., Hogg \& Abrams, 1988; Tajfel \& Turner, 1979). Where leadership is invested in a group rather than a single individual, these processes are likely to be much amplified.

Another potential problem with prototype-based leadership arises because as people identify more strongly with a group (the group becomes more cohesive), leadership becomes increasingly based on prototypicality rather than leader schemas or intrinsic status characteristics. In group decision-making contexts this can degrade decision-making processes. Rather than basing leadership on leader schemas that generally contain optimal situation and task-specific leadership prescriptions, a situation can exist where there is a powerful leader who embodies a group prototype that does not prescribe optimal decision-making procedures. This may produce groupthink (Janis, 1972); powerful leaders and the absence of norms for optimal decision making conspire in highly cohesive groups to produce suboptimal decision-making procedures that lead to poor decisions (Hogg \& Hains, 1998; M. E. Turner, Pratkanis, Probasco, \& Leve, 1992).

Another pitfall of prototype-based leadership is that social minorities (e.g., based on race, ethnicity, gender, disability) may find it difficult to assume leadership roles in some contexts. For example, if the normative environment for business, or the organizational culture within specific organizations, renders social minorities intrinsically less prototypical than majorities, then minorities will find it more difficult to achieve and maintain an effective leadership role (see Hogg \& Terry, 2000). Highly cohesive groups with focused prototypes also often have members who identify very strongly with the group because the group very effectively reduces extreme subjective uncertainty. These groups are particularly prone to hierarchical leadership structures with remote and powerful leaders who are invested with enormous charisma and who can exercise and abuse their position of power.

\section{Some Caveats and Clarifications}

The theory of leadership I present here is intended to describe the role of social identity processes in all forms of leadership: Under appropriate conditions prototypicality has a significant effect on emergent as well as established leadership in groups ranging from small task-oriented teams to entire nations. Most direct tests of the theory have, however, focused-under controlled experimental conditions-on emergent leadership in short-lived laboratory groups. Although this research has been essential, it has operationalized prototypes as a unidimensional construct, whereas in fact prototypes are complex multidimensional fuzzy sets. Leaders probably have much greater latitude to maintain power when they are located by a multidimensional prototype than a unidimensional prototype. It may be easier for leaders to acquire and maintain power by emphasizing different aspects of the prototype than by trying to keep unchanged a single group-defining attribute.

Many groups exist primarily to perform specific tasks (e.g., work teams), and thus, members of these groups may focus on how competent the leader is-leadership effectiveness may rest heavily on perceived leader competence. Indeed, specific status characteristics and situation/task-specific leader schemas embody leadership attributes such as competence. These are very sound bases for effective leadership that often dominate leadership processes. My theory does not disagree with this. The theory simply states that under certain circumstances, self-definition as a group member may be extremely salient, in which case group prototype-based depersonalization becomes an important basis of leadership. This process may be more powerful in groups that are strongly defined in terms of identity rather than the performance of a specific task, but given the right circumstances, even task-oriented groups may focus on self-definitional group norms rather than task performance.

\section{Concluding Comments}

Leadership research along with research on small groups and intragroup processes lost popularity with social psychologists in the 1960s. Since the early 1970s, social psychology has made enormous advances in the study of social cognition and intergroup relations, which together have recently revived interest in the study of group phenomena. Social identity theory has become an important part of this integration and shift of interest within social psychology. Social psychology is now poised to revisit group phenomena with new, more sophisticated theories, concepts, and 
methodologies. In this article I have sketched out a social identity theory of group leadership.

Aggregates of individuals mainly base their leadership perceptions and endorsements on judgements of how well individuals fit the specifications of situation and task-specific schemas of types of leaders. However, as the aggregate increasing becomes a psychological group - a collection of people who categorize themselves in terms of the same descriptive and prescriptive ingroup prototype-leadership perceptions and endorsements are increasingly influenced by how well individuals match the group prototype. In very cohesive groups with which members identify very strongly, leadership processes will be strongly determined by prototypicality. However, prototypicality alone does not imply active leadership. Prototypical members do not actively lead but rather appear to have influence; they act as the attitudinal and behavioral focus of the group due to self-categorization based prototypical depersonalization processes. It is social attraction, an associated effect of depersonalization, that facilitates active influence.

Group membership based social attraction enables the leader to secure compliance with suggestions and recommendations and also endows the leader with status and evaluative differentiation from the rest of the group. The leader now occupies a high-status role and is able to be actively innovative. The third process is an attributional one through which followers, influenced by correspondence bias and the fundamental attribution error, attribute the leaders influence, status, popularity, and ability to innovate and lead, internally to the leader's personality, thus constructing a charismatic leadership personality for the leader that further reifies the leader's distinctive status within the group.

I reviewed empirical evidence for this analysis of leadership. Direct tests have focused on the fundamental core prediction that as a group becomes more salient emergent leadership processes and leadership effectiveness perceptions become less dependent on leader schema congruence and more dependent on group prototypicality. There is solid support for this idea from laboratory experiments (e.g., Duck \& Fielding, 1999; Hains et al., 1997; Hogg et al., 1998; Platow \& van Knippenberg, 1999) and a naturalistic field study (Fielding \& Hogg, 1997). There is also indirect support from a range of studies of leadership that are in the social identity tradition (de Cremer \& van Vugt, in press; Foddy \& Hogg, 1999; Haslam et al., 1998; Platow et al., 1998; van Vugt \& de Cremer, 1999). There is also support for the idea that prototype-based depersonalized social attraction may facilitate leadership. There is some direct evidence from the studies by Fielding and Hogg (1997) and de Cremer and van Vugt (in press), whereas in other studies social attraction is a component of the leadership evaluation measure (e.g., Hains et al., 1997; Hogg et al., 1998). The attribution and associated structural differentiation components of the theory have indirect support (e.g., Fiske,1993; Fiske \& Dépret, 1996), but remain to be directly tested. This and further research is currently under way. It should, however, be recognized that the empirical status of the leadership theory rests on good evidence for social identity theory as a whole.

On the basis of what we know so far, we could now advise leaders of cohesive groups to pay attention to how prototypical they are to remain in power, and leaders of less cohesive groups to pay attention to how well they match task and situation specific leader schemas. Put differently, prototypical leaders would do well to raise group solidarity and cohesion while accentuating their prototypicality, whereas nonprototypical leaders should lower solidarity and cohesion while accentuating how well they match leader schemas.

The social identity theory of leadership has many additional complexities that are described in this article; these are extensions and implications that are speculative and still need to be fully explored conceptually and empirically. For example, social attraction and prototypical attribution processes may transform a prototypical ingroup leader into a high status role occupant who has a charismatic leadership personality. A structural differentiation is created within the group that severs the empathic bond between leader(s) and followers and instantiates a form of intergroup relations. This transforms influence into power and provides a social structural framework that makes very real the opportunity to abuse power. Another example is that conditions of high subjective uncertainty encourage the formation of very cohesive groups with high entitativity and clearly focused and consensual prototypes. These groups tend not only to be very extreme, but also to have a steep and rigid leadership structure with a highly charismatic leader. The leader is often considered God-like by followers and exercises enormous power, often in deleterious ways. A final example is that encounters between leaders of different groups can be particularly effective in engaging prototype-based leadership processes, which can have undesirable consequences if the encounter was intended to provide a context for negotiation to resolve intergroup differences.

In conclusion, the social identity theory of leadership views leadership as a group process that arises from the social categorization and depersonalization processes associated with social identity. Prototype-based depersonalization and the behavior of followers play a critical role: They empower individuals as leaders, imbue them with charisma, create a status differential between leader(s) and followers that has some of the typical characteristics of uneven status intergroup relations, and set up conditions that are con- 
ducive to the exercise and possible abuse of power. These ideas are a potentially rich source of conceptual explorations and basic and applied empirical research into social identity and leadership.

\section{References}

Abrams, D., \& Hogg, M. A. (1988). Comments on the motivational status of self-esteem in social identity and intergroup discrimination. European Journal of Social Psychology, 18, 317-334.

Abrams, D., \& Hogg, M. A. (Eds.). (1990). Social identity theory: Constructive and critical advances. Hemel Hempstead, England: Harvester Wheatsheaf.

Abrams, D., \& Hogg, M. A. (1998). Prospects for research in group processes and intergroup relations. Group Processes and Intergroup Relations, 1, 7-20.

Abrams, D., \& Hogg, M. A. (Eds.). (1999). Social identity and social cognition. Oxford, England: Blackwell.

Abrams, D., Wetherell, M. S., Cochrane, S., Hogg, M. A., \& Turner, J. C. (1990). Knowing what to think by knowing who you are: Self-categorization and the nature of norm formation, conformity, and group polarization. British Journal of Social Psychology, 29, 97-119.

Albright, L., \& Forziati, C. (1995). Cross-situational consistency and perceptual accuracy in leadership. Personality and Social Psychology Bulletin, 21, 1269-1276.

Bales, R. F. (1950). Interaction process analysis: A method for the study of small groups. Reading, MA: Addison-Wesley.

Bass, B. M. (1985). Leadership and performance beyond expectations. New York: Free Press.

Bass, B. M. (1990a). Bass and Stogdill's handbook of leadership: Theory, research and managerial applications. New York: Free Press.

Bass, B. M. (1990b). From transactional to transformational leadership: Learning to share the vision. Organizational Dynamics, $18,19-31$.

Bass, B. M. (1998). Transformational leadership: Industrial, military, and educational impact. Mahwah, NJ: Lawrence Erlbaum Associates, Inc.

Bass, B. M., \& Avolio, B. J. (1993). Transformational leadership: A response to critiques. In M. M. Chemers \& R. A. Ayman (Eds.), Leadership theory and research: Perspectives and directions (pp. 49-80). London: Academic.

Berger, J., Fisek, M. H., Norman, R. Z., \& Zelditch, M., Jr. (1977). Status characteristics and social interaction. New York: Elsevier.

Berscheid, E., \& Reis, H. T. (1998). Attraction and close relationships. In D. T. Gilbert, S. T. Fiske, \& G. Lindzey (Eds.), The handbook of social psychology (4th ed., Vol. 2, pp. 193-281). New York: McGraw-Hill.

Brewer, M. B., \& Harasty, A. S. (1996). Seeing groups as entities: The role of perceiver motivation. In E. T. Higgins \& R. M. Sorrentino (Eds.), Handbook of motivation and cognition, Vol. 3: The interpersonal context (pp. 347-370). New York: Guilford.

Bryman, A. (1992). Charisma and leadership in organizations. London: Sage.

Burns, J. M. (1978). Leadership. New York: Harper \& Row.

Campbell, D. T. (1958). Common fate, similarity, and other indices of the status of aggregates of persons as social entities. Behavioral Science, 3, 14-25.

Capozza, D., \& Brown, R. (Eds.). (2000). Social identity processes. London: Sage.
Carnevale, P. J. D., Pruitt, D. G., \& Britton, S. D. (1979). Looking tough: The negotiator under constituent surveillance. Personality and Social Psychology Bulletin, 5, 118-121.

Chemers, M. M. (1987). Leadership processes: Intrapersonal, interpersonal, and societal influences. In C. Hendrick (Ed.), Review of personality and social psychology (Vol. 8, pp. 252-277). Newbury Park, CA: Sage.

Chemers, M. M. (2001). Leadership effectiveness: An integrative review. In M. A. Hogg \& R. S. Tindale (Eds.), Blackwell handbook of social psychology: Group processes (pp. 376-399). Oxford, England: Blackwell.

Conger, J. A., \& Kanungo, R. N. (1987). Towards a behavioral theory of charismatic leadership in organizational settings. Academy of Management Review, 12, 637-647.

Conger, J. A., \& Kanungo, R. N. (1988). Behavioral dimensions of charismatic leadership. In J. A. Conger \& R. N. Kanungo (Eds.), Charismatic leadership: The elusive factor on organizational effectiveness (pp. 309-323). San Francisco: Jossey-Bass.

Crocker, J., Blaine, B., \& Luhtanen, R. (1993). Prejudice, intergroup behaviour and self-esteem: Enhancement and protection motives. In M. A. Hogg \& D. Abrams (Eds.), Group motivation: Social psychological perspectives (pp. 52-67). Hemel Hempstead, England: Harvester Wheatsheaf.

Crocker, J., \& Luhtanen, R. (1990). Collective self-esteem and ingroup bias. Journal of Personality and Social Psychology, 58, 60-67.

Curtis, J. M., \& Curtis, M. J. (1993). Factors related to susceptibility and recruitment by cults. Psychological Reports, 73, 451-460.

de Cremer, D., \& van Vugt, M. (in press). Intergroup and intragroup dynamics of leadership in social dilemmas: A relational model of cooperation. Journal of Experimental Social Psychology.

Duck, J. M., \& Fielding, K. S. (1999). Leaders and sub-groups: One of us or one of them? Group Processes and Intergroup Relations, 2, 203-230.

Eagly, A. H., Karau, S. J., \& Makhijani, M. G. (1995). Gender and the effectiveness of leaders: A meta-analysis. Psychological Bulletin, 117, 125-145.

Ellemers, N. (1993). The influence of socio-structural variables on identity enhancement strategies. European Review of Social Psychology, 4, 27-57.

Ellemers, N., Spears, R., \& Doosje, B. (Eds.). (1999). Social identity. Oxford, England: Blackwell.

Erber, R., \& Fiske, S. T. (1984). Outcome dependency and attention to inconsistent information. Journal of Personality and Social Psychology, 47, 709-726.

Fiedler, F. E. (1965). A contingency model of leadership effectiveness. In L. Berkowitz (Ed.), Advances in experimental social psychology (Vol. 1, pp. 149-190). New York: Academic.

Fiedler, F. E. (1971). Leadership. Morristown, NJ: General Learning Press.

Fiedler, F. E., \& House, R. J. (1994). Leadership theory and research: A report of progress. In C. L. Cooper \& I. T. Robertson (Eds.), Key reviews in managerial psychology: Concepts and research for practice (pp. 97-116). Chichester, England: Wiley.

Fielding, K. S., \& Hogg, M. A. (1997). Social identity, self-categorization, and leadership: A field study of small interactive groups. Group Dynamics: Theory, Research, and Practice, 1, 39-51.

Fiske, S. T. (1993). Controlling other people: The impact of power on stereotyping. American Psychologist, 48, 621-628.

Fiske, S. T., \& Dépret, E. (1996). Control, interdependence and power: Understanding social cognition in its social context. European Review of Social Psychology, 7, 31-61.

Fiske, S. T., \& Taylor, S. E. (1991). Social cognition (2nd ed.). New York: McGraw-Hill.

Foddy, M., \& Hogg, M. A. (1999). Impact of leaders on resource consumption in social dilemmas: The intergroup context. In M. Foddy, M. Smithson, S. Schneider, \& M. A. Hogg (Eds.), Resolving social dilemmas: Dynamic, structural, and intergroup aspects (pp. 309-330). Philadelphia: Psychology Press. 
Galanter, M. (Ed.). (1989). Cults and new religious movements. Washington, DC: American Psychiatric Association.

Gilbert, D. T., \& Jones, E. E. (1986). Perceiver-induced constraint: Interpretations of self-generated reality. Journal of Personality and Social Psychology, 50, 269-280.

Gilbert, D. T., \& Malone, P. S. (1995). The correspondence bias. Psychological Bulletin, 117, 21-38.

Goodwin, S. A., \& Fiske, S. T. (1996). Judge not, lest ...: The ethics of power holders' decision making and standards for social judgment. In D. M. Messick \& A. E. Tenbrunsel (Eds.), Codes of conduct: Behavioral research into business ethics (pp. 117-142). New York: Russell Sage Foundation.

Goodwin, S. A., Gubin, A., Fiske, S. T., \& Yzerbyt, V. Y. (2000). Power can bias impression processes: Stereotyping subordinates by default and by design. Group Processes and Intergroup Relations, 3, 227-256.

Graumann, C. F., \& Moscovici, S. (Eds.). (1986). Changing conceptions of leadership. New York: Springer-Verlag.

Grieve, P., \& Hogg, M. A. (1999). Subjective uncertainty and intergroup discrimination in the minimal group situation. Personality and Social Psychology Bulletin, 25, 926-940.

Hains, S. C., Hogg, M. A., \& Duck, J. M. (1997). Self-categorization and leadership: Effects of group prototypicality and leader stereotypicality. Personality and Social Psychology Bulletin, $23,1087-1100$.

Hall, R. J., \& Lord, R. G. (1995). Multi-level information processing explanations of followers' leadership perceptions. Leadership Quarterly, 6, 265-287.

Hamilton, D. L., \& Sherman, S. J. (1996). Perceiving persons and groups. Psychological Review, 103, 336-355.

Haslam, S. A., McGarty, C., Brown, P. M., Eggins, R. A., Morrison, B. E., \& Reynolds, K. J. (1998). Inspecting the emperor's clothes: Evience that random selection of leaders can enhance group performance. Group Dynamics: Theory, Research, and Practice, 2, 168-184.

Haslam, S. A., Oakes, P. J., McGarty, C., Turner, J. C., \& Onorato, S (1995). Contextual changes in the prototypicality of extreme and moderate outgroup members. European Journal of Social Psychology, 25, 509-530.

Haslam, S. A., \& Platow, M. J. (2001). Your wish is our command: The role of shared social identity in translating a leader's vision into followers' action. In M. A. Hogg \& D. J. Terry (Eds.), Social identity processes in organizational contexts (pp. 213-228). Philadelphia: Psychology Press.

Hogg, M. A. (1992). The social psychology of group cohesiveness: From attraction to social identity. New York: New York University Press.

Hogg, M. A. (1993). Group cohesiveness: A critical review and some new directions. European Review of Social Psychology, 4, 85-111.

Hogg, M. A. (1996a). Intragroup processes, group structure and social identity. In W. P. Robinson (Ed.), Social groups and identities: Developing the legacy of Henri Tajfel (pp. 65-93). Oxford, England: Butterworth-Heinemann.

Hogg, M. A. (1996b). Social identity, self-categorization, and the small group. In E. H. Witte \& J. H. Davis (Eds.), Understanding group behavior. Vol. 2: Small group processes and interpersonal relations (pp. 227-253). Mahwah, NJ: Lawrence Erlbaum Associates, Inc.

Hogg, M. A. (2000a). Social identity and social comparison. In J. Suls \& L. Wheeler (Eds.), Handbook of social comparison: Theory and research (pp. 401-421). New York: Plenum.

Hogg, M. A. (2000b). Subjective uncertainty reduction through self-categorization: A motivational theory of social identity processes. European Review of Social Psychology, 11, 223-255.
Hogg, M. A. (2001). Social categorization, depersonalization, and group behavior. In M. A. Hogg \& R. S. Tindale (Eds.), Blackwell handbook of social psychology: Group processes (pp. 56-85). Oxford, England: Blackwell.

Hogg, M. A., \& Abrams, D. (1988). Social identifications: A social psychology of intergroup relations and group processes. London: Routledge.

Hogg, M. A., \& Abrams, D. (1990). Social motivation, self-esteem and social identity. In D. Abrams \& M. A. Hogg (Eds.), Social identity theory: Constructive and critical advances (pp. 28-47). New York: Springer-Verlag.

Hogg, M. A., \& Abrams, D. (1993). Towards a single-process uncertainty-reduction model of social motivation in groups. In M. A. Hogg \& D. Abrams (Eds.), Group motivation: Social psychological perspectives (pp. 173-190). London: Harvester-Wheatsheaf.

Hogg, M. A., \& Abrams, D. (1999). Social identity and social cognition: Historical background and current trends. In D. Abrams \& M. A. Hogg (Eds.), Social identity and social cognition (pp. 1-25). Oxford, England: Blackwell.

Hogg, M. A., Cooper-Shaw, L., \& Holzworth, D. W. (1993). Group prototypicality and depersonalized attraction in small interactive groups. Personality and Social Psychology Bulletin, 19, 452-465.

Hogg, M. A., \& Grieve, P. (1999). Social identity theory and the crisis of confidence in social psychology: A commentary, and some research on uncertainty reduction. Asian Journal of Social Psychology, 2, 79-93.

Hogg, M. A., \& Hains, S. C. (1996). Intergroup relations and group solidarity: Effects of group identification and social beliefs on depersonalized attraction. Journal of Personality and Social Psychology, 70, 295-309.

Hogg, M. A., \& Hains, S. C. (1998). Friendship and group identification: A new look at the role of cohesiveness in groupthink. European Journal of Social Psychology, 28, 323-341.

Hogg, M. A., Hains, S. C., \& Mason, I. (1998). Identification and leadership in small groups: Salience, frame of reference, and leader stereotypicality effects on leader evaluations. Journal of Personality and Social Psychology, 75, 1248-1263.

Hogg, M. A., \& Hardie, E. A. (1991). Social attraction, personal attraction and self-categorization: A field study. Personality and Social Psychology Bulletin, 17, 175-180.

Hogg, M. A., Hardie, E. A., \& Reynolds, K. (1995). Prototypical similarity, self-categorization, and depersonalized attraction: A perspective on group cohesiveness. European Journal of Social Psychology, 25, 159-177.

Hogg, M. A., \& Mullin, B.-A. (1999). Joining groups to reduce uncertainty: Subjective uncertainty reduction and group identification. In D. Abrams \& M. A. Hogg (Eds.), Social identity and social cognition (pp. 249-279). Oxford, England: Blackwell.

Hogg, M. A., \& Reid, S. A. (2001). Social identity, leadership, and power. In A. Y. Lee-Chai \& J. A. Bargh (Eds.), The use and abuse of power: Multiple perspectives on the causes of corruption (pp. 159-180). Philadelphia: Psychology Press.

Hogg, M. A., \& Terry, D. J. (2000). Social identity and self-categorization processes in organizational contexts. Academy of Management Review, 25, 121-140.

Hogg, M. A., Terry, D. J., \& White, K. M. (1995). A tale of two theories: A critical comparison of identity theory with social identity theory. Social Psychology Quarterly, 58, 255-269.

Hollander, E. P. (1958). Conformity, status, and idiosyncracy credit. Psychological Review, 65, 117-127.

Hollander, E. P. (1985). Leadership and power. In G. Lindzey \& E. Aronson (Eds.), The handbook of social psychology (3rd ed., Vol. 2, pp. 485-537). New York: Random House.

Hollander, E. P., \& Julian, J. W. (1969). Contemporary trends in the analysis of leadership processes. Psychological Bulletin, 71, 387-391. 
Hollander, E. P., \& Julian, J. W. (1970). Studies in leader legitimacy, influence, and innovation. In L. Berkowitz (Ed.), Advances in experimental social psychology (Vol. 5, pp. 34-69). New York: Academic.

Hornsey, M. J., \& Hogg, M. A. (1999). Subgroup differentiation as a response to an overly-inclusive group: A test of optimal distinctiveness theory. European Journal of Social Psychology, 29, 543-550.

Hornsey, M. J., \& Hogg, M. A. (2000a). Intergroup similarity and subgroup relations: Some implications for assimilation. Personality and Social Psychology Bulletin, 26, 948-959.

Hornsey, M. J., \& Hogg, M. A. (2000b). Subgroup relations: A comparison of mutual intergroup differentiation and common ingroup identity models of prejudice reduction. Personality and Social Psychology Bulletin, 26, 242-256.

Janis, I. L. (1972). Victims of groupthink: A psychological study of foreign policy decisions and fiascoes. Boston: Houghton Mifflin.

Jetten, J., Hogg, M. A., \& Mullin, B.-A. (2000). Ingroup variability and motivation to reduce subjective uncertainty. Group Dynamics: Theory, Research, and Practice, 4, 184-198.

Jones, E. E. (1998). Major developments in five decades of social psychology. In D. T. Gilbert, S. T. Fiske, \& G. Lindzey (Eds.), The handbook of social psychology (4th ed., Vol. 1, pp. 3-57). New York: McGraw-Hill.

Jost, J. T., \& Banaji, M. R. (1994). The role of stereotyping in system-justification and the production of false consciousness. British Journal of Social Psychology, 33, 1-27.

Kenny, D. A., \& Zaccaro, S. J. (1983). An estimate of variance due to traits in leadership. Journal of Applied Psychology, 68, 678-685.

Lind, E. A., \& Tyler, T. R. (1988). The social psychology of procedural justice. New York: Henry Holt.

Lippitt, R., \& White, R. (1943). The 'social climate' of children's groups. In R. G. Barker, J. Kounin, \& H. Wright (Eds.), Child behavior and development (pp. 485-508). New York: McGraw-Hill.

Long, M. K., \& Spears, R. (1997). The self-esteem hypothesis revisited: Differentiation and the disaffected. In R. Spears, P. J. Oakes, N. Ellemers, \& S. A. Haslam (Eds.), The social psychology of stereotyping and group life (pp. 296-317). Oxford, England: Blackwell.

Lord, R. G., Brown, D. J., \& Harvey, J. L. (2001). System constraints on leadership perceptions, behavior and influence: An example of connectionist level processes. In M. A. Hogg \& R. S. Tindale (Eds.), Blackwell handbook of social psychology: Group processes (pp. 283-310). Oxford, England: Blackwell.

Lord, R. G., Foti, R. J., \& DeVader, C. L. (1984). A test of leadership categorization theory: Internal structure, information processing, and leadership perceptions. Organizational Behavior and Human Performance, 34, 343-378.

Lord, R. G., \& Maher, K. J. (1991). Leadership and information processing: Linking perceptions and performance. Winchester, MA: Unwin Hyman.

Luhtanen, R., \& Crocker, J. (1992). A collective self-esteem scale: Self-evaluation of one's social identity. Personality and Social Psychology Bulletin, 18, 302-318.

Marques, J. M., \& Páez, D. (1994). The black sheep effect: Social categorization, rejection of ingroup deviates, and perception of group variability. European Review of Social Psychology, 5, $37-68$.

Marris, P. (1996). The politics of uncertainty: Attachment in private and public life. London: Routledge.

McGarty, C., Turner, J. C., Hogg, M. A., David, B., \& Wetherell, M. S. (1992). Group polarization as conformity to the prototypical group member. British Journal of Social Psychology, 31, 1-20.
McGrath, J. E. (1997). Small group research, that once and future field: An interpretation of the past with an eye to the future. Group Dynamics: Theory, Research, and Practice, 1, 7-27.

Meindl, J. R., Ehrlich, S. B., \& Dukerich, J. M. (1985). The romance of leadership. Administrative Science Quarterly, 30, 78-102.

Moreland, R. L., Hogg, M. A., \& Hains, S. C. (1994). Back to the future: Social psychological research on groups. Journal of Experimental Social Psychology, 30, 527-555.

Morley, I. E., Webb, J., \& Stephenson, G. M. (1988). Bargaining and arbitration in the resolution of conflict. In W. Stroebe, A. W. Kruglanski, D. Bar-Tal, \& M. Hewstone (Eds.), The social psychology of intergroup conflict: Theory, research, and applications (pp. 117-134). Berlin: Springer-Verlag.

Morris, M. W., \& Peng, K. (1994). Culture and cause: American and Chinese attributions for social and physical events. Journal of Personality and Social Psychology, 67, 949-971.

Mowday, R. T., \& Sutton, R. I. (1993). Organizational behavior: Linking individuals and groups to organizational contexts. Annual Review of Psychology, 44, 195-229.

Mullen, B., Salas, E., \& Driskell, J. E. (1989). Salience, motivation, and artifact as contributions to the relation between participation rate and leadership. Journal of Experimental Social Psychology, 25, 545-559.

Mullin, B.-A., \& Hogg, M. A. (1998). Dimensions of subjective uncertainty in social identification and minimal intergroup discrimination. British Journal of Social Psychology, 37, 345-365.

Mullin, B.-A., \& Hogg, M. A. (1999). Motivations for group membership: The role of subjective importance and uncertainty reduction. Basic and Applied Social Psychology, 21, 91-102.

Nye, J. L., \& Forsyth, D. R. (1991). The effects of prototype-based biases on leadership appraisals: A test of leadership categorization theory. Small Group Research, 22, 360-379.

Nye, J. L., \& Simonetta, L. G. (1996). Followers' perceptions of group leaders: The impact of recognition-based and inference-based processes. In J. L. Nye \& A. M. Bower (Eds.), What's social about social cognition: Research on socially shared cognition in small groups (pp. 124-153). Thousand Oaks, CA: Sage.

Oakes, P. J., Haslam, S. A., \& Turner, J. C. (1994). Stereotyping and social reality. Oxford, England: Blackwell.

Palich, L. E., \& Hom, P. W. (1992). The impact of leader power and behavior on leadership perceptions: A lisrel rest of an expanded categorization theory of leadership model. Group and Organization Management, 17, 279-296.

Pawar, B. S., \& Eastman, K. (1997). The nature and implications of contextual influences on transformational leadership. Academy of Management Review, 22, 80-109.

Peters, L. H., Hartke, D. D., \& Pohlmann, J. T. (1985). Fielder's contingency theory of leadership: An application of the meta-analytic procedure of Schmidt and Hunter. Psychological Bulletin, 97, 287-300.

Platow, M. J., Reid, S., \& Andrew, S. (1998). Leadership endorsement: The role of distributive and procedural behavior in interpersonal and intergroup contexts. Group Processes and Intergroup Relations, 1, 35-47.

Platow, M. J., \& van Knippenberg, D. (1999, July). The impact of leaders' ingroup prototypicality and normative fairness on leadership endorsements in an intergroup context. Paper presented at the XII General Meeting of the European Association of Experimental Social Psychology, Oxford, England.

Rabbie, J. M., \& Bekkers, F. (1978). Threatened leadership and intergroup competition. European Journal of Social Psychology, 8 , 9-20.

Raven, B. H. (1965). Social influence and power. In I. D. Steiner \& M. Fishbein (Eds.), Current studies in social psychology (pp. 371-382). New York: Holt, Rinehart \& Winston. 
Reicher, S. D., \& Hopkins, N. (1996). Seeking influence through characterising self-categories: An analysis of anti-abortionist rhetoric. British Journal of Social Psychology, 35, 297-311.

Ridgeway, C. L. (2001). Social status and group structure. In M. A. Hogg \& R. S. Tindale (Eds.), Blackwell handbook of social psychology: Group processes (pp. 352-375). Oxford, England: Blackwell.

Robinson, W. P. (Ed.). (1996). Social groups and identities: Developing the legacy of Henri Tajfel. Oxford, England: Butterworth-Heinemann.

Ross, L. (1977). The intuitive psychologist and his shortcomings. In L. Berkowitz (Ed.), Advances in experimental social psychology (Vol. 10, pp. 174-220). New York: Academic.

Rubin, M., \& Hewstone, M. (1998). Social identity theory's self-esteem hypothesis: A review and some suggestions for clarification. Personality and Social Psychology Review, 2, 40-62.

Rush, M. C., \& Russell, J. E. A. (1988). Leader prototypes and prototype-contingent consensus in leader behavior descriptions. Journal of Experimental Social Psychology, 24, 88-104.

Sanna, L. J., \& Parks, C. D. (1997). Group research trends in social and organizational psychology: Whatever happened to intragroup research? Psychological Science, 8, 261-267.

Sherif, M. (1966). In common predicament: Social psychology of intergroup conflict and cooperation. Boston: Houghton Mifflin.

Stogdill, R. (1974). Handbook ofleadership. New York: Free Press.

Strube, M. J., \& Garcia, J. E. (1981). A meta-analytic investigation of Fiedler's contingency model of leadership effectiveness. Psychological Bulletin, 90, 307-321.

Tajfel, H. (1959). Quantitative judgement in social perception. British Journal of Psychology, 50, 16-29.

Tajfel, H. (1969). Cognitive aspects of prejudice. Journal of Social Issues, 25, 79-97.

Tajfel, H. (1972). Social categorization. English manuscript of 'La catégorisation sociale.' In S. Moscovici (Ed.), Introduction à la Psychologie Sociale (Vol. 1, pp. 272-302). Paris: Larousse.

Tajfel, H., \& Turner, J. C. (1979). An integrative theory of intergroup conflict. In W. G. Austin \& S. Worchel (Eds.), The social psychology of intergroup relations (pp. 33-47). Monterey, CA: Brooks/Cole.

Taylor, S. E., \& Fiske, S. T. (1975). Point-of-view and perceptions of causality. Journal of Personality and Social Psychology, 32, 439-445.

Taylor, S. E., \& Fiske, S. T. (1978). Salience, attention, and attribution: Top of the head phenomena. In L. Berkowitz (Ed.), $A d$ vances in experimental social psychology (Vol. 11, pp. 249-288). New York: Academic.

Trope, Y., \& Liberman, A. (1993). The use of trait conceptions to identify other people's behavior and to draw inferences about their personalities. Personality and Social Psychology Bulletin, $19,553-562$

Turner, J. C. (1975). Social comparison and social identity: Some prospects for intergroup behaviour. European Journal of Social Psychology, 5, 5-34.
Turner, J. C. (1982). Towards a cognitive redefinition of the social group. In H. Tajfel (Ed.), Social identity and intergroup relations (pp. 15-40). Cambridge, England: Cambridge University Press.

Turner, J. C. (1985). Social categorization and the self-concept: A social cognitive theory of group behavior. In E. J. Lawler (Ed.), Advances in group processes: Theory and research (Vol. 2, pp. 77-122). Greenwich, CT: JAI.

Turner, J. C. (1991). Social influence. Buckingham, England: Open University Press.

Turner, J. C. (1999). Some current issues in research on social identity and self-categorization theories. In N. Ellemers, R. Spears, \& B. Doosje (Eds.), Social identity (pp. 6-34). Oxford, England: Blackwell.

Turner, J. C., Brown, R. J., \& Tajfel, H. (1979). Social comparison and group interest in ingroup favouritism. European Journal of Social Psychology, 9, 187-204.

Turner, J. C., Hogg, M. A., Oakes, P. J., Reicher, S. D., \& Wetherell, M. S. (1987). Rediscovering the social group: A self-categorization theory. Oxford, England: Blackwell.

Turner, M. E., Pratkanis, A. R., Probasco, P., \& Leve, C. (1992). Threat, cohesion, and group effectiveness: Testing a social identity maintenance perspective on groupthink. Journal of Personality and Social Psychology, 63, 781-796.

Tyler, T. R. (1997). The psychology of legitimacy: A relational perspective on voluntary deference to authorities. Personality and Social Psychology Review, 1, 323-345.

Tyler, T. R., DeGoey, P., \& Smith, H. (1996). Understanding why the justice of group procedures matters: A test of the psychological dynamics of the group-value model. Journal of Personality and Social Psychology, 70, 913-930.

Tyler, T. R., \& Lind, E. A. (1992). A relational model of authority in groups. In M. P. Zanna (Ed.), Advances in experimental social psychology (Vol. 25, pp. 115-191). New York: Academic.

van Vugt, M., \& de Cremer, D. (1999). Leadership in social dilemmas: The effects of group identification on collective actions to provide public goods. Journal of Personality and Social Psychology, 76, 587-599.

Wilpert, B. (1995). Organizational behavior. Annual Review of Psychology, 46, 59-90.

Worchel, S., Morales, J. F., Páez, D., \& Deschamps, J.-C. (Eds.). (1998). Social identity: International perspectives. London: Sage.

Yukl, G. (1981). Leadership in organizations. Englewood Cliffs, NJ: Prentice Hall.

Yukl, G. A., \& Falbe, C. M. (1991). Importance of different power sources in downward and lateral relations. Journal of Applied Psychology, 76, 416-423.

Yukl, G., \& Van Fleet, D. D. (1992). Theory and research on leadership in organizations. In M. D. Dunnette \& L. M. Hough (Eds.), Handbook of organizational psychology (2nd ed., Vol. 3, pp. 147-197). Palo Alto, CA: Consulting Psychologists Press. 